\title{
DYNAMICS OF THE NUMBER OF PERSONS WITH SPECIAL NEEDS LIVING IN ZAKARPATTIA OBLAST, UKRAINE
}

DOI: 10.36740/WLek202006135

\author{
Ivan S. Myronyuk, Gennadiy 0. Slabkiy, Nataliya 0. Kabatsiy, Lesya V. Levko \\ UZHHOROD NATIONAL UNIVERSITY, UZHHOROD, UKRAINE
}

\begin{abstract}
The aim: To study and analyze indicators of the number of persons with special needs living in Transcarpathian region of Ukraine: disabled persons, orphans and children deprived of parental care.

Materials and methods: National statistical reports on the disability of the population, the number of orphans and children deprived of parental care for the period 20102019. Statistical method was applied in the course of study.

Results: Analysis of the dynamics of the number of persons with special needs in Transcarpathian region for the period 2010-2019 showed an increase of the number of disabled persons by $27 \%$ with 75415 persons, 6826 disabled children, 2125 orphans and children deprived of parental care. The number of orphans and children deprived of parental care residing in the region have a tendency to reduce and in the year 2019 equals to 2125 orphans and children deprived of parental care.This requires improving of the system of social and medical care for persons with special needs for adults with the formation of a system of provision of services in accordance with the actual needs of the population with the maximum approximation of the service to the place of residence of the client with the maximum use of opportunities of the united territorial communities.

Conclusions: The growth of the number of persons with special needs in Transcarpathian region and directly of the persons with disabilities with the tendency to reduce the number of orphans and children deprived of parental care is established.
\end{abstract}

KEY WORDS: disabled persons, orphans, children deprived of parental care

Wiad Lek. 2020;73(6):1261-1263

\section{INTRODUCTION}

Up to $15 \%$ of Ukraine's residents are disabled. The annual primary disability rate is up to 36 per 10 thousand people and it tends to increase $[1,2]$. The number of orphans and children deprived of parental care is also increasing [3].

Due to health problems, persons with special needs require special measures to be taken by state and public institutions to ensure their full participation in social life, equally with the others. $[6,7]$. At the present stage of society's development, the activities of all national institutions, including state authorities, public associations, etc., should be aimed at creating conditions in which persons with special needs can lead an independent lifestyle and take an active part in all spheres of life. [8,9].

\section{THE AIM}

Aim of the study: to study and analyze indicators of the number of persons with special needs (persons with disabilities, orphans and children deprived of parental care) living in Zakarpattia oblast.

\section{MATERIALS AND METHODS}

The sources of the study were data from the scientific literature on the research problem and state statistical reports on the numbers of disabled persons, orphans, and children deprived of parental care. The study covered the period from 2010 to 2019.

During the study, the following methods were used: a systematic approach, biblical semantic and medical statistical methods.

\section{RESULTS AND DISCUSSION}

At the beginning of the study, the amount of people with disabilities living in Zakarpattia oblast was examined. The study covers the period from 2010 to 2019 . The obtained data are shown in Table I.

The analysis of the data in Table 1 reveals that there are 75415 disabled persons in Zakarpattia oblast, which is 12337 more than in 2010. The structure of the number of persons with disabilities includes $8.0 \%$ - the first disability group, $27.3 \%$ - the second disability group and $64.7 \%$ - the third disability group.

The number of children with disabilities living in Zakarpattia oblast was further examined. The results obtained are shown in Figure 1.

As of the end of 2019, there were 6826 children with disabilities living in Zakarpattia oblast, which is 1536 (29.0\%) more than in 2010. Disabled children make up 2.34\% of the total amount of children living in the region. 
Table I. Number of persons with disabilities, Zakarpattia oblast (2010-2019).

\begin{tabular}{cccccccc}
\hline \multirow{2}{*}{ Year } & \multirow{2}{*}{ Total } & \multicolumn{2}{c}{ Group I } & \multicolumn{2}{c}{ Group II } & \multicolumn{2}{c}{ Group III } \\
\cline { 3 - 8 } & & abs & $\%$ & abs & a & abs & 27093 \\
\hline 2010 & 63078 & 6114 & 9,7 & 24581 & 38,9 & 51,4 \\
\hline 2015 & 71930 & 6274 & 8,7 & 22160 & 30,8 & 37403 & 60,5 \\
\hline 2016 & 72334 & 6189 & 8,6 & 21557 & 29,8 & 38303 & 61,6 \\
\hline 2017 & 73197 & 6119 & 8,4 & 21152 & 28,9 & 39458 & 62,7 \\
\hline 2018 & 74206 & 6101 & 8,2 & 20873 & 28,1 & 40557 & 63,7 \\
\hline 2019 & 75415 & 6054 & 8,0 & 20556 & 27,3 & 41979 & 64,7 \\
\hline 2019 to 2010 & +12337 & -60 & $-1,7$ & -4025 & $-11,6$ & +14886 & $+13,3$ \\
\hline
\end{tabular}

Table II. Statistical data on orphans and children deprived of parental care and their adoption, Zakarpattia oblast (2010-2018).

\begin{tabular}{ccccccc} 
Indicator & $\mathbf{2 0 1 0}$ & $\mathbf{2 0 1 5}$ & $\mathbf{2 0 1 6}$ & $\mathbf{2 0 1 7}$ & $\mathbf{2 0 1 8}$ & $\mathbf{2 0 1 8}$ to $\mathbf{2 0 1 0}$ \\
\hline $\begin{array}{c}\text { The total number of orphans } \\
\text { and children deprived of parental care }\end{array}$ & 2326 & 2301 & 2261 & 2216 & 2125 & -201 \\
\hline Number of children adopted during a year (abs) & 120 & 106 & 99 & 87 & 107 & -13 \\
\hline Percentage of children adopted during a year (\%) & 5,2 & 4,6 & 4,4 & 3,9 & 5,0 & $-0,2$ \\
\hline
\end{tabular}

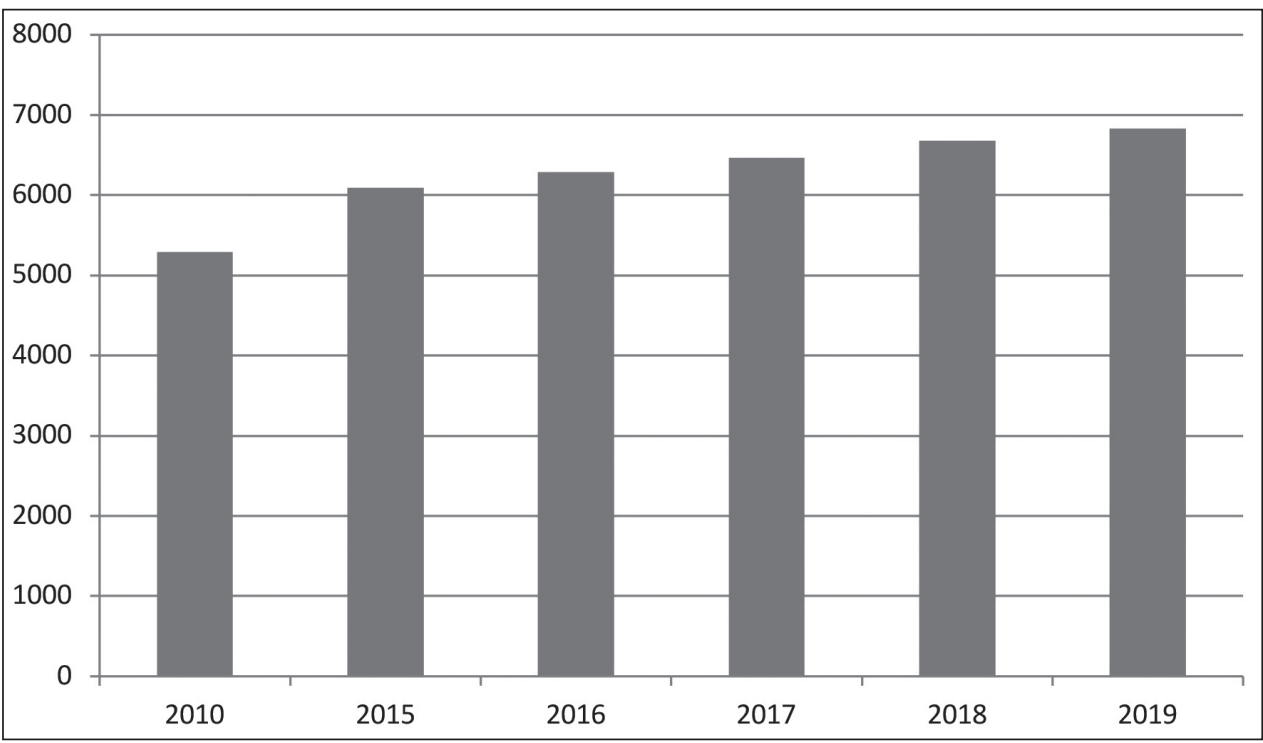

Fig. 1. Number of children with disabilities, in Zakarpattia oblast, 2010-2018.

The next step of the research was to study statistical data on orphans and children deprived of parental care and their adoption in Zakarpattia oblast. The data obtained in the dynamics of 2010-2018 are shown in the Table II.

For the period 2010-2018, the number of orphans and children deprived of parental care in the region decreased by 201 to 2125 , which is $0.73 \%$ of the total amount of children living in the region. The share of adopted children decreased from $5.2 \%$ to $5.0 \%$ and in 2018 amounted to 107 children.

The analysis of the dynamics of the number of persons with special needs in Zakarpattia oblast for the period 2010-2019 showed an increase in the number of persons with disabilities by $27 \%$ with their number 75415 persons, with a tendency to decrease the number of orphans and children deprived of parental care with the number of 6826 children with disabilities and 2,125 orphans and children deprived of parental care.

This requires improving the system of social and medical care for persons with special needs for adults with the formation of a system of provision of services in accordance with the actual needs of the population with the maximum approximation of the service to the place of residence of the client with the maximum use of opportunities of the united territorial communities.

Care and upbringing of children should be carried out in a family-friendly environment, providing conditions for living close to family conditions (food, clothing, footwear, hard and soft equipment, housekeeping, leisure activities, etc.), developing and maintaining self-care skills, household skills necessary for the organization of independent life; education and development of individual abilities, 
assistance in obtaining educational, medical, rehabilitation and social services in appropriate institutions.

\section{CONCLUSIONS}

The growth of the number of persons with special needs in Transcarpathian region and directly of the persons with disabilities with the tendency to reduce the number of orphans and children deprived of parental care is established.

\section{REFERENCES}

1. Ipatov, A. V., Moroz, 0. M., Holyk V. A. [And Others]. Osnovni pokaznyky invalidnosti ta diialnosti medyko-sotsialnykh ekspertnykh komisii Ukrainy za 2015 rik [Main indicators of disability and activity of medical and social expert commissions of Ukraine in 2015]. Analytical and information guide. Dnipropetrovs'k: Accent Private Enterprise; 2016, 162 p. (UA)

2. Shevchuk, V. I., Belyayeva, N. M., Storozhuk, L. O. [and others]. Osnovni pokaznyky medyko-sotsialnoi reabilitatsii osib z invalidnistiu v Ukraini za 2017 rik [The main indicators of medical and social rehabilitation of persons with disabilities in Ukraine for 2017]. Analytical and information guide.Vinnytsia: Rohalska I.0. Individual Entrepreneur; 2018, 122 p. (UA)

3. Voronenko, Y.V., Hoyda, N.H., Moiseyenko, R.O. Suchasni aspekty rozvytku systemy medyko-sotsialnykh posluh dlia urazlyvykh hrup ditei v Ukraini [Current aspects of development of the system of medical and social services for vulnerable groups of children in Ukraine]. Sovremennaia pedyatryia. 2014; 8 (64): 39-43. (UA)

4. World Health Organization / World Bank World report on disability. Geneva:WHO, 2011. — 38 p. URL: http:// www.who.int/disabilities/ world_report/2011/report/en

5. World Health Organization. Disability и rehabilitation. Medical care and rehabilitation: what WHO is doing. URL: http://www.who.int/ disabilities/care/activities/ru/

6. Teoriya sotsylnoy raboty. 2nd edition supplemented and revised. Under the scientific editorship of S.G. Furdeia. Rostov-on-Don: Nauka-Press Publishing House; 2006, 256 p. (RU)
7. Shoshmin, A. V., Martynova, N. V., Besstrashnova, Y. K. i dr. Osnovy upravleniya reabilitatsionnyimi resursami. St. Petersburg: Federal State Budgetary Institution «Federal Scientific Center of Rehabilitation of the Disabled named after G.A. Albrecht»». 2009, 96 p. (RU)

This study (article) was carried out as a part of the research Work "The scientific rationale for monitoring the factors affecting the health of the population of the Transcarpathian region and the formation of modern management in the health care system". State registration number 3A-2015No.0115U003907 dated 01/01/2016.

\section{ORCID and contributionship:}

Ivan S. Myronyuk - 0000-0003-4203-4447 ${ }^{A, C, E}$

Gennady O. Slabkiy - 0000-0003-2308-7869 ${ }^{B, D, F}$

Nataliya O. Kabatsiy -0000-0003-1853-3473 ${ }^{C, F}$

Lesya V. Levko - 0000-0003-1340-4162 B,E

\section{Conflict of interest:}

The Authors declare no conflict of interest.

\author{
CORRESPONDING AUTHOR \\ Gennady 0. Slabkiy \\ Uzhhorod National University, \\ Sq. Narodna 3, 88000 Uzhhorod, Ukraine \\ tel : +38(050)171-16-48 \\ e-mail : g.slabkiy@ukr.net
}

Received: 02.03 .2020

Accepted: 04.05.2020 